\title{
ANALISIS POLA DISTRIBUSI DAN POLA PERUBAHAN SUHU PERMUKAAN TANAH DI KOTA SURABAYA MENGGUNAKAN CITRA LANDSAT 8 DAN STASIUN CUACA OTOMATIS
}

\author{
Firmansyah Maulana Azhali ${ }^{1}$ dan Lalu Muhamad Jaelani ${ }^{2}$ \\ 1,2 Departemen Teknik Geomatika, FTSLK-ITS, Kampus ITS Sukolilo, Surabaya, 60111, Indonesia \\ e-mail: ${ }^{2}$ Imjaelani@geodesy.its.ac.id
}

\begin{abstract}
Abstrak
Kepadatan penduduk di daerah perkotaan berimplikasi terhadap ketersediaan ruang terbuka hijau (RTH) yang terbatas. RTH memiliki peran penting untuk menjaga kualitas lingkungan dan kesehatan masyarakat yang tinggal di daerah tersebut. Untuk itu diperlukan sebuah indicator berupa Suhu Permukaan Tanah (SPT) untuk mengetahui sebaran dan kecukupan RTH di kawasan tertentu. Data SPT kontinyu selanjutnya dapat dijadikan dasar dalam pembangunan dan manajemen RTH. SPT dapat diperoleh dengan perekaman data meterologi menggunakan stasiun cuaca. Namun data yang diperoleh terbatas secara jumlah dan sebaran spasial. Sehingga pemanfaatan citra satelit dengan sensor termal menjadi sebuah solusi untuk mendapatkan SPT dengan cakupan area yang luas. Pada penelitian ini, analisis perubahan suhu dilakukan di Kota Surabaya dengan menggunakan data Landsat 8 TIRS pada tanggal 5 Agustus 2018 sampai 12 September 2018. Hasil dari estimasi SPT dengan metode Single-Channel Algorithm (SCA) kemudian divalidasi dengan suhu yang terekam pada Stasiun Cuaca Juanda (BMKG Juanda) dan Stasiun Cuaca Otomatis ITS (PWS ITS). Pada periode 5 Agustus 2018 hingga 12 September 2018 , SPT maksimum, minimum dan rata-rata di Surabaya adalah $36^{\circ} \mathrm{C}, 20^{\circ} \mathrm{C}$ dan $27^{\circ} \mathrm{C}$. Terdapat perbedaaan suhu antara LST dan BMKG Juanda sebesar $\pm 0,11^{\circ} \mathrm{C}$ (11 Agustus 2018) dan $\pm 0,34^{\circ} \mathrm{C}(12$ September 2018). Sementara beda suhu antara LST dan PWS ITS adalah $\pm 0,88^{\circ} \mathrm{C}$ (11 Agustus 2018) dan $\pm 3,22^{\circ} \mathrm{C}(12$ September 2018). Hasil uji korelasi antara data SPT dengan BMKG Juanda dan PWS ITS menunjukkan adanya korelasi yang sangat kuat antara kedua data $(R=87 \%)$.
\end{abstract}

Kata Kunci : AWS, Citra Landsat 8, SCA, SPT

\begin{abstract}
Population density in urban areas has implications for the limited availability of green open space. Green open space has an important role in maintaining the quality of the environment and the health of the people living in the area. For this reason, an indicator in the form of Ground Surface Temperature is needed to determine the distribution and adequacy of green open space in a certain area. Continuous ground surface temperature data can then be used as the basis for the development and management of green open space. Ground Surface Temperature can be obtained by recording meteorological data using a weather station. However, the data obtained are limited in number and spatial distribution. So that the use of satellite imagery with thermal sensors becomes a solution to get Ground Surface Temperature with a wide area coverage. In this study, the analysis of temperature changes was carried out in the city of Surabaya using the Landsat 8 TIRS data from August 52018 to September 12 2018. The results of the Ground Surface Temperature estimation using the Single-Channel Algorithm (SCA) method were then validated with the temperature recorded at the Juanda Weather Station (BMKG Juanda) and ITS Automatic Weather Station (ITS PWS). In the period 5 August 2018 to 12 September 2018, the maximum, minimum and average of Ground Surface Temperature in Surabaya is $36^{\circ} \mathrm{C}, 20^{\circ} \mathrm{C}$ and $27^{\circ} \mathrm{C}$. There is a difference in temperature between LST and BMKG Juanda of $\pm 0.11^{\circ} \mathrm{C}\left(11\right.$ August 2018) and $\pm 0.34^{\circ} \mathrm{C}(12$ September 2018). While the temperature difference between LST and PWS ITS is $\pm 0.88^{\circ} \mathrm{C}$ (11 August 2018) and $\pm 3.22^{\circ} \mathrm{C}$ (12 September 2018). The results of the correlation test between SPT data with BMKG Juanda and PWS ITS showed a very strong correlation between the two data $(R=87 \%)$.
\end{abstract}

Keywords : AWS, Landsat 8 imagery, SCA, Ground Surface Temperature 


\section{PENDAHULUAN}

Dalam perencanaan pembangunan ruang terbuka hijau, estimasi Suhu Permukaan Tanah (SPT) berfungsi untuk mengetahui daerah mana yang memiliki distribusi SPT yang tinggi sehingga nantinya dapat dijadikan kajian untuk perencanaan pembangunan hutan kota maupun taman kota. Sejak 2010, Walikota Surabaya Tri Rismaharini sangat gencar dalam pembangunan taman kota dan hutan kota. Pembangunan taman tersebut menyebabkan menurunnya SPT Kota Surabaya sebanyak $2^{\circ} \mathrm{C}$ (Hakim, 2018).

SPT adalah salah satu parameter kunci keseimbangan energi pada permukaan dan merupakan variabel klimatologis yang utama. SPT mengendalikan fluks energi gelombang panjang yang melalui atmosfer. Besarnya suhu permukaan tergantung kondisi parameter permukaan lainnya, seperti albedo, kelembaban permukaan dan tutupan lahan serta kondisi vegetasi (Prasasti, dkk, 2007). SPT merupakan fenomena penting dalam perubahan iklim global. Seiring meningkatnya kandungan gas rumah kaca di atmosfer, maka SPT juga akan meningkat. Hal ini akan mengakibatkan mencairnya gletser dan lapisan es dan mempengaruhi vegetasi daerah tersebut. Dampaknya akan lebih banyak di daerah monsun, karena curah hujan tidak dapat diprediksi mengakibatkan banjir dan kenaikan permukaan air laut (Rajeshwari \& Mani, 2014).

Pada pengolahan SPT menggunakan citra Landsat 8, kanal 11 sudah tidak efektif lagi dikarenakan ada stray light yang mempengaruhi kalibrasi absolut sensor termal Landsat 8 (TIRS) sejak peluncurannya. Dampak dari stray light berbeda-beda pada setiap kanal, salah satunya pada sensor kanal 11. Saat ini sedang dikembangkan algoritma untuk mengkalibrasi sensor kanal 11 (USGS, 2017). Karena kanal 11 tidak baik digunakan untuk pengolahan suhu permukaan tanah maka berkembanglah algoritma Single-Channel Algorithm (SCA) sebagai alternatif untuk estimasi SPT (Walawender, dkk, 2014).

Pada awalnya, penelitian SPT menggunakan data meteorologi dari stasiun cuaca. Hal ini menyebabkan sulitnya memperoleh data meteorologi yang berlimpah dan tidak memungkinkan untuk memperoleh data meteorologi pada permukaan selain dari lokasi stasiun cuaca. Setelah peluncuran satelit Sputnik pada 1957, citra satelit banyak diaplikasikan untuk berbagai macam kebutuhan. Citra satelit dengan thermal infrared kanal seperti Landsat TM, Landsat OLI, ASTER dan TERRA-MODIS dapat digunakan untuk estimasi SPT (Tsou, dkk, 2017).

Stasiun Cuaca Otomatis (AWS) adalah stasiun yang melakukan pengukuran yang mengirim atau mencatat hasil pengamatan unsur-unsur cuaca secara otomatis dan secara langsung membuat kode-kode yang telah dikonversi. AWS umumnya dilengkapi dengan beberapa sensor, RTU (Remote Terminal Unit), seperangkat komputer dengan layar LED, dan bagian bagian lainnya. Sensor yang digunakan meliputi sensor suhu, sensor arah dan kecepatan angin, sensor kelembaban, sensor tekanan udara, presipitasi, pyranometer, dan net radio meter. RTU terdiri atas data logger dan daya cadangan yang berfungsi sebagai terminal tempat pengumpulan data cuaca yang berasal dari sensor tersebut (Qudratullah, dkk, 2017). Sistem pengamatan AWS sudah cukup lama dikembangkan di negara maju, namun harganya cukup mahal sehingga masih sangat terbatas digunakan di Indonesia (Nugroho, 2016).

Pada penelitian ini, citra satelit Landsat 8 dan AWS dimanfaatkan untuk menganalisis pola perubahan SPT sehingga dihasilkan Peta Distribusi SPT 1:200.000. Peta Distribusi SPT digunakan untuk mengetahui anomali dan tren suhu di Kota Surabaya. Data pola perubahan SPT digunakan untuk mengetahui variasi SPT secara temporal tentang tren pola perubahan suhu di Kota Surabaya.

\section{METODOLOGI PENELITIAN}

\section{Lokasi Penelitian}

Penelitian ini dilakukan di Kota Surabaya yang terletak di $07^{\circ} 12^{\prime}-07^{\circ} 21^{\prime}$ Lintang Selatan dan $112^{\circ} 36^{\prime}-112^{\circ} 54^{\prime}$ Bujur Timur. Berikut merupakan gambar dari lokasi penelitian yang ditunjukkan seperti gambar berikut ini: 


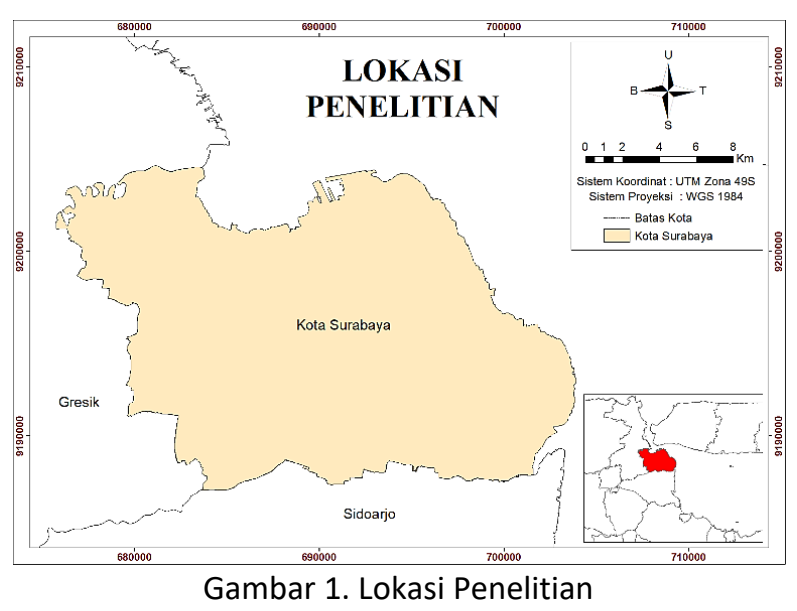

\section{Data dan Peralatan}

Data yang digunakan untuk penelitian ini yaitu citra satelit resolusi menengah Landsat 8 level 1 dan 2 wilayah Surabaya yang diakuisisi pada 11 Agustus 2018 dan 12 September 2018, vektor batas administrasi Kota Surabaya yang diperoleh dari BIG skala 1:25.000, data suhu dari PWS ITS dan BMKG Juanda.

Adapun perangkat lunak yang digunakan dalam penelitian ini adalah ArcMAP 10.6.1 lisensi edukasi ITS untuk mengolah citra, mengolah IDW dan pembuatan peta.

\section{Tahapan Pengolahan Suhu Permukaan Tanah}

Tahapan pengolahan SPT diawali dengan kalibrasi radiometrik. Kalibrasi radiometrik dilakukan untuk mengonversi nilai piksel dari digital number (DN) menjadi brightness temperature (BT). Selain konversi DN menjadi brightness temperature (BT), DN juga dikonversikan menjadi radian dan reflektan. Berikut adalah persamaan untuk perhitungan kalibrasi radiometrik (Jaelani, 2013):

$L_{\lambda}=M_{L} Q_{\text {cal }}+A_{L}$

Di mana:

$L_{\lambda}=$ TOA spectral radiance $\left(\frac{w}{m^{2} \text { srad } \mu m}\right)$

$\rho_{\lambda}=$ TOA spectral reflectance

$M_{L}=$ Band specific multiplicative rescaling factor

$A_{L}=$ Band specific addiitive rescaling factor

$Q_{c a l}=$ Nilai Digital Number (DN) pada kanal yang dituju

$B T=\frac{K_{2}}{\ln \left(\frac{K_{1}}{L_{\lambda}}+1\right)}$
Di mana:

$B T=$ Brightness temperature $\left({ }^{\circ} \mathrm{K}\right)$

$L_{\lambda}=$ Spectral radiance $\left(\frac{w}{m^{2} \text { srad } \mu m}\right)$

$K_{1}=$ Konstanta thermal conversion untuk kanal 10

$K_{2}=$ Konstanta thermal conversion untuk kanal 10

Koreksi atmosfer dilakukan pada kanal 4 dan 5 untuk mengonversi nilai radian pada sensor satelit $\left(L_{\text {TOA }}\right)$ dan reflektan pada sensor satelit $\left(\rho_{\text {TOA }}\right)$ menjadi nilai radian dibawah lapisan atmofer $\left(L_{B O A}\right)$ dan nilai reflektan dibawah lapisan atmofer $\left(\rho_{B O A}\right)$. Pada penelitian ini koreksi atmosfer menggunakan citra Landsat 8 level 2. Citra Landsat 8 level 2 dipilih karena algoritma level 2 lebih baik dibandingkan algoritma 6S (Second Simulation of the Satellite Signal in the Solar Spectrum) yang membutuhkan banyak parameter, sehingga apabila terjadi kesalahan pemilihan parameter maka akan berdampak pada pengolahan berikutnya. NDVI dilakukan dengan pengolahan citra dengan mengombinasikan kanal 4 dan 5 yang telah terkoreksi atmosfer menjadi citra baru yang menunjukkan nilai kehijauan dari citra tersebut. Persamaan yang digunakan untuk mendapatkan nilai NDVI adalah sebagai berikut (Waas \& Nababan, 2010):

$N D V I=\frac{\left(\rho_{B O A} N I R-\rho_{B O A} R e d\right)}{\left(\rho_{B O A} N I R+\rho_{B O A} \text { Red }\right)}$

Di mana:

NDVI = Nilai Normalized Difference Vegetation Index

$\rho_{\text {BOA(NIR) }}=$ Nilai reflektan dibawah lapisan atmosfer untuk kanal 5

$\rho_{\text {BOA }(\text { Red })}=$ Nilai reflektan dibawah lapisan atmosfer untuk kanal 4

Proportion of vegetation (Pv) dibutuhkan untuk mengetahui parameter emisivitas dengan melihat dari nilai NDVI yang telah diolah sebelumnya. Dalam penelitian ini, nilai koefisien $\mathrm{NDVI}_{\mathrm{s}}$ dan koefisien $\mathrm{NDVI}_{\mathrm{v}}$ ditentukan dengan nilai 0,2 untuk $\mathrm{NDVI}_{\mathrm{s}}$ dan 0,5 untuk NDVI $\mathrm{I}_{\mathrm{v}}$. Nilai tersebut dapat diaplikasikan dalam segala kondisi secara global (Sobrino \& Raissouni, 2000). Persamaan untuk memperoleh nilai Pv adalah sebagai berikut: 


$$
P v=\left(\frac{N D V I-N D V I_{s}}{N D V I_{v}-N D V I_{s}}\right)^{2}
$$

Land Surface Emissivity (LSE) dibutuhkan untuk mendapatkan nilai emisivitas $(\varepsilon)$ yang nantinya akan dimasukkan pada rumus perhitungan SPT. Nilai emisivitas dari piksel tanah $\left(\mathrm{NDVI}<\mathrm{NDVI}_{\mathrm{s}}\right)$ adalah 0,96 ( $\mathrm{Pv}=0$ dan $C_{\lambda}=0$, jadi $\left.\varepsilon_{\lambda}=\varepsilon_{s \lambda}=0,96\right)$ dan nilai emisivitas dari piksel vegetasi (NDVI > NDVI $)$ adalah 0,99 ( $\mathrm{Pv}=1$ dan $C_{\lambda}$ $=0,005$, jadi $\left.\varepsilon_{\lambda}=\varepsilon_{v \lambda}+C_{\lambda}=0,985+0,005=0,99\right)$. Nilai emisivitas campuran dapat dihitung menggunakan persamaan berikut (Sobrino, et al., 1990):

$\varepsilon_{\lambda}=\varepsilon_{v \lambda} P v+\varepsilon_{s \lambda}(1-P v)+C_{\lambda}$

Di mana:

$$
\begin{aligned}
\varepsilon_{v \lambda} & =0,985 \\
\varepsilon_{s \lambda} & =0,960 \\
C_{\lambda} & =0,005 \text { (konstanta) }
\end{aligned}
$$

Atmospheric Correction Parameter Calculator adalah web-based tools yang digunakan untuk memperoleh parameter koreksi atmosfer. Selanjutnya parameter koreksi atmosfer diolah menggunakan persamaan berikut untuk memperoleh nilai fungsi atmosferik (Walawender, et al., 2014):

$\psi_{1}=\frac{1}{\tau} \quad \psi_{2}=-L^{\downarrow}-\frac{L^{\uparrow}}{\tau} \quad \psi_{3}=L^{\downarrow}$

Di mana $\tau$ adalah atmospheric transmissivity, $L^{\uparrow}$ adalah up-welling radiance atau cahaya yang dipancarkan dan $L^{\downarrow}$ adalah downwelling radiance atau cahaya yang meredup. Koreksi pengaruh atmosfer memerlukan parameter atmosfer yang spesifik $\left(\tau, L^{\uparrow}, L^{\downarrow}\right)$ (Barsi, et al., 2003). SPT adalah persamaan yang digunakan untuk memperoleh distribusi SPT dari citra satelit. Estimasi SPT metode SCA dapat dilakukan menggunakan persamaan berikut (Jimenez-Munoz, et al., 2009):

$S C A=\gamma\left[\frac{1}{\varepsilon}\left(\psi_{1} L_{S}+\psi_{2}\right)+\psi_{3}\right]+\delta$

Di mana $\varepsilon$ adalah Land Surface Emissivity (LSE), $\gamma$ dan $\delta$ adalah parameter yang bergantung pada fungsi Planck, dan $\psi_{1}, \psi_{2}$ dan $\psi_{3}$ adalah fungsi atmosferik (AFs). Dalam upaya mendapatkan hasil SPT dalam satuan celcius, maka setiap tahapan pengolahan yang menggunakan satuan kelvin harus dikonversikan dalam celcius terlebih dahulu. Tahapan-tahapan yang dimaksudkan adalah pengolahan brightness temperature (BT) dan gamma ( $\gamma$ ). Untuk memperoleh nilai $\gamma$ dan $\delta$ dapat menggunakan persamaan berikut:

$\gamma=\left\{\frac{C_{2} L_{S}}{T_{S}^{2}}\left[\frac{\lambda^{4} L_{S}}{C_{1}}+\frac{1}{\lambda}\right]\right\}^{-1}$

$\delta=-\gamma \cdot L_{s}+T_{s}$

Di mana $C_{1}$ dan $C_{2}$ adalah konstanta radiasi planck $\left(C_{1}=1,1910410^{8} \mathrm{~W} \mu \mathrm{m}^{4} \mathrm{~m}^{-2} \mathrm{sr}^{-1} ; C_{2}=1,43877\right.$ $\left.10^{4} \mu \mathrm{m}^{0} \mathrm{~K}\right)$; dan $\lambda$ adalah panjang gelombang efektif $(\lambda=10,895 \mu \mathrm{m}$ untuk Landsat-8 OLI dan TIRS Kanal 10). Untuk memperoleh nilai gamma dalam satuan celcius, maka nilai konstanta radiasi planck $\left(C_{2}\right)$ harus dicari menggunakan persamaan berikut (Sobrino, 2010):

$C_{2}=\lambda \times K_{2}$

Di mana $\lambda$ adalah panjang gelombang efektif $(\lambda=10,895 \mu \mathrm{m}$ untuk Landsat-8 OLI/ TIRS kanal 10) dan $K_{2}$ adalah konstanta termal suatu gelombang. Nilai $\mathrm{K}_{2}$ untuk Landsat-8 OLI dan TIRS kanal 10 adalah $1321,0789^{\circ} \mathrm{K}$ atau $1047,9289^{\circ} \mathrm{C}$. Setelah semua variabel memiliki satuan celcius maka selanjutnya dimasukkan kedalam persamaan SCA.

\section{Tahapan Pengolahan Data Meteorologi}

Pengolahan data meteorologi pada AWS dan Stasiun Cuaca terdiri atas pengunduhan data, integrasi data, pemodelan grafik. Tahap pengunduhan data adalah tahapan di mana peneliti mengumpulkan data dari berbagai macam sumber. Tahap integrasi data adalah tahapan untuk merekap hasil data yang telah diunduh dan dilakukan konversi satuan untuk selanjutnya dapat digunakan untuk pemodelan dan validasi SPT. Tahap pemodelan grafik adalah tahapan untuk memodelkan data suhu untuk diketahui pola perubahannya dalam kurun waktu 1 (satu) bulan. Selain pemodelan grafik bulanan, pemodelan grafik harian dilakukan untuk memperoleh tren pola perubahan suhu harian pada waktu akuisisi citra satelit. 


\section{Tahapan Validasi dan Analisis Akhir}

Tahap validasi dan analisis akhir terdiri dari uji korelasi, validasi data dan ekstrapolasi data meteorologi AWS. Uji korelasi pearson digunakan untuk melihat keberadaan hubungan dari nilai suhu permukaan yang dihasilkan dari pengolahan SPT metode SCA dengan nilai suhu permukaan yang dihasilkan oleh AWS. Nilai koefisien korelasi diperoleh menggunakan persamaan berikut (Hidayat, 2012):

$R_{x y}=\frac{n \sum x_{i} y_{i}-\sum x_{i} \sum y_{i}}{\sqrt{n \sum x_{i}{ }^{2}-\left(\sum x_{i}\right)^{2}} \cdot \sqrt{n \sum y_{i}{ }^{2}-\left(\sum y_{i}\right)^{2}}}$

Hasil perhitungan koefisien korelasi selanjutnya digunakan untuk mengetahui kekuatan korelasinya. Nilai kekuatan korelasi dapat dilihat pada Tabel 1 tentang interval kekuatan korelasi (Sarwono, 2006):

Tabel 1. Interval kekuatan korelasi

\begin{tabular}{ccc}
\hline No. & $\begin{array}{c}\text { Koefisien } \\
\text { Korelasi }\end{array}$ & Kekuatan Korelasi \\
\hline 1 & 0 & Tidak ada \\
2 & $0,00-0,25$ & Sangat lemah \\
3 & $0,25-0.50$ & Cukup \\
4 & $0,50-0,75$ & Kuat \\
5 & $0,75-0,99$ & Sangat kuat \\
6 & 1 & Sempurna \\
\hline \hline
\end{tabular}

Validasi digunakan untuk pengecekan nilai suhu permukaan lahan hasil pengolahan citra dengan data suhu permukaan yang diperoleh dari AWS. Interpolasi adalah tahapan untuk menentukan nilai diantara dua nilai yang diketahui berdasarkan suatu fungsi persamaan.

\section{HASIL DAN PEMBAHASAN}

\section{Hasil Suhu Permukaan Tanah}

Hasil pengolahan SPT diperoleh dengan metode SCA. Dalam memudahkan proses analisis, batas atas dan batas bawah hasil pengolahan SPT diatur pada $40^{\circ} \mathrm{C}$ dan $25^{\circ} \mathrm{C}$. Berikut adalah hasil pengolahan SPT:

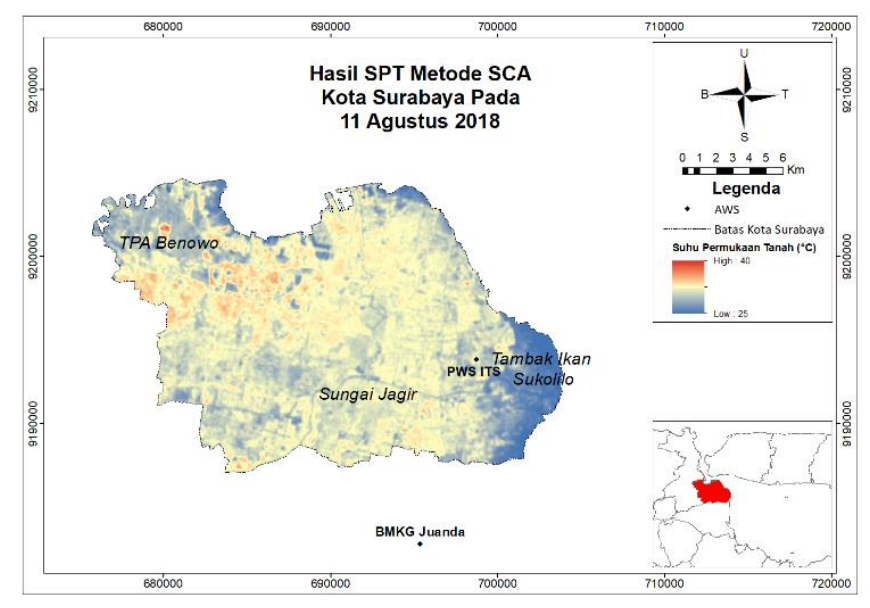

Gambar 2. Hasil pengolahan SPT metode SCA pada Citra Landsat 8 akuisisi 11 Agustus 2018

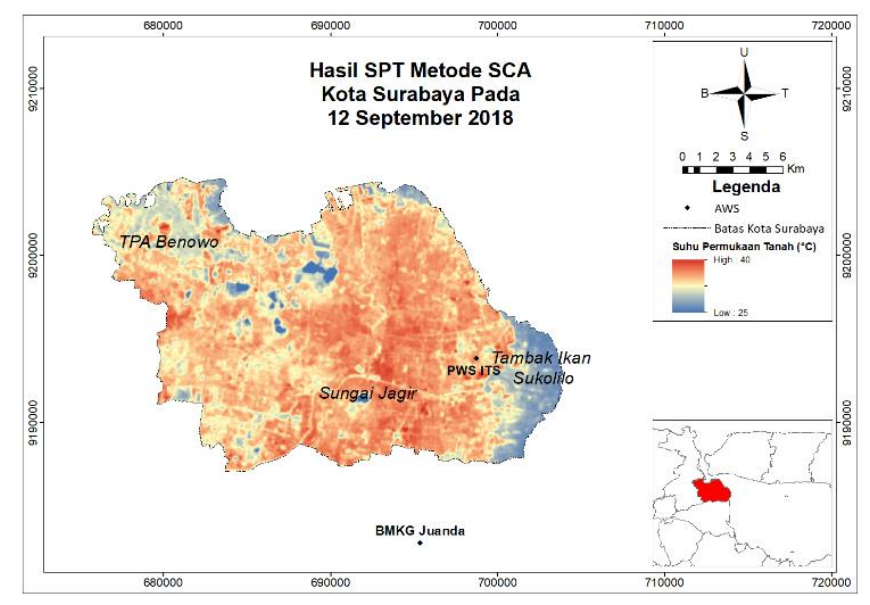

Gambar 3. Hasil pengolahan SPT metode SCA pada Citra Landsat 8 akuisisi 12 September 2018

Hasil pengolahan SPT metode SCA yang telah dilakukan dapat dilihat pada Gambar 2 dan 3. Perubahan warna pada hasil pengolahan memiliki makna yang berbeda, warna merah berarti SPT yang tinggi dan warna biru berarti SPT yang rendah.

Pada kedua hasil pengolahan SPT terdapat kesamaan pola yaitu suhu rendah yang membentuk sebuah jalur. Setelah dilakukan pencarian melalui Google Earth (GE) ditemukan bahwa lokasi tersebut adalah Sungai Jagir. Hasil perbandingan pengolahan SPT dengan GE dapat dilihat pada Gambar 4 tentang anomali Sungai Jagir.

Selain anomali suhu rendah yang membentuk jalur, terdapat juga hotspot dibagian utara Kota Surabaya tepatnya pada perbatasan dengan Kota Gresik. Setelah dilakukan pencarian melalui GE ditemukan bahwa lokasi tersebut adalah Tempat Pembuangan Akhir Benowo. Pada TPA 
Benowo terdapat aktifitas Gasifikasi atau pembakaran sampah untuk memperoleh energi listrik. Kegiatan pembakaran sampah tersebut menyebabkan suhu permukaan disekitar TPA Benowo meningkat (Dofir, 2018). Hasil perbandingan pengolahan SPT dengan GE dapat dilihat pada Gambar 5 tentang anomali Tempat Pembuangan Akhir Benowo.

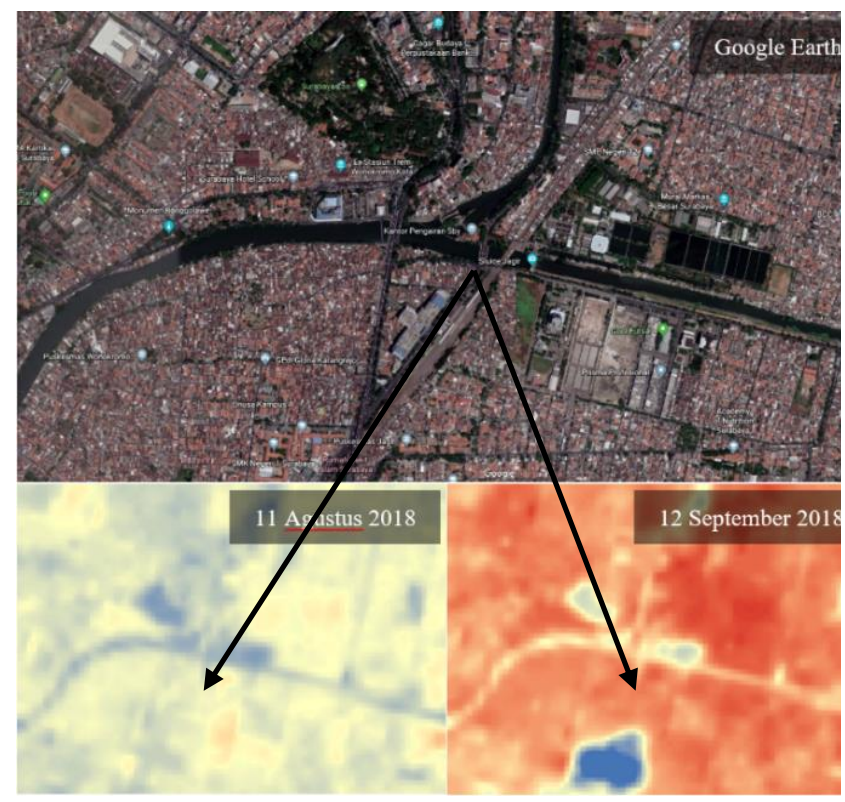

Gambar 4. Anomali pola suhu rendah Sungai Jagir

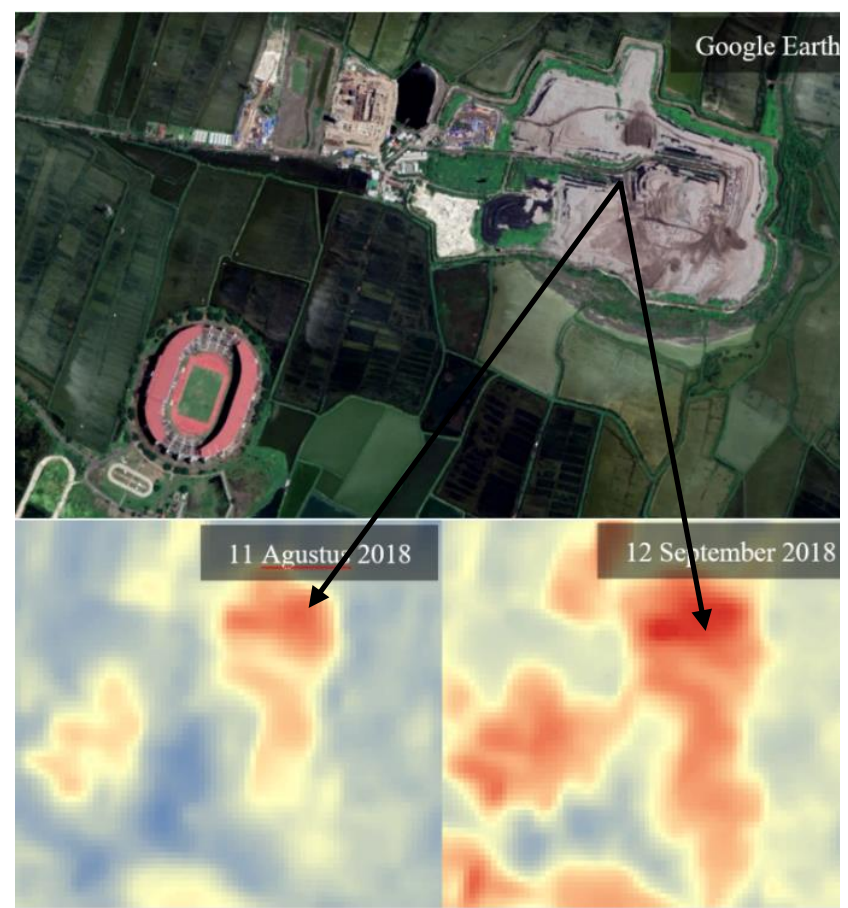

Gambar 5. Anomali pola suhu tinggi Tempat Pembuangan Akhir (TPA) Benowo

Terdapat juga pola suhu permukaan yang rendah pada Kecamatan Sukolilo, Surabaya Timur. Setelah dilakukan pencarian melalui GE ditemukan bahwa lokasi tersebut adalah Tambak Ikan di Kelurahan Sukolilo, Kecamatan Sukolilo dan Hutan Mangrove di Kelurahan Wonorejo, Kecamatan Rungkut. Hasil perbandingan pengolahan SPT dengan GE dapat dilihat pada Gambar 6 tentang anomali pola suhu rendah pada Surabaya Timur.

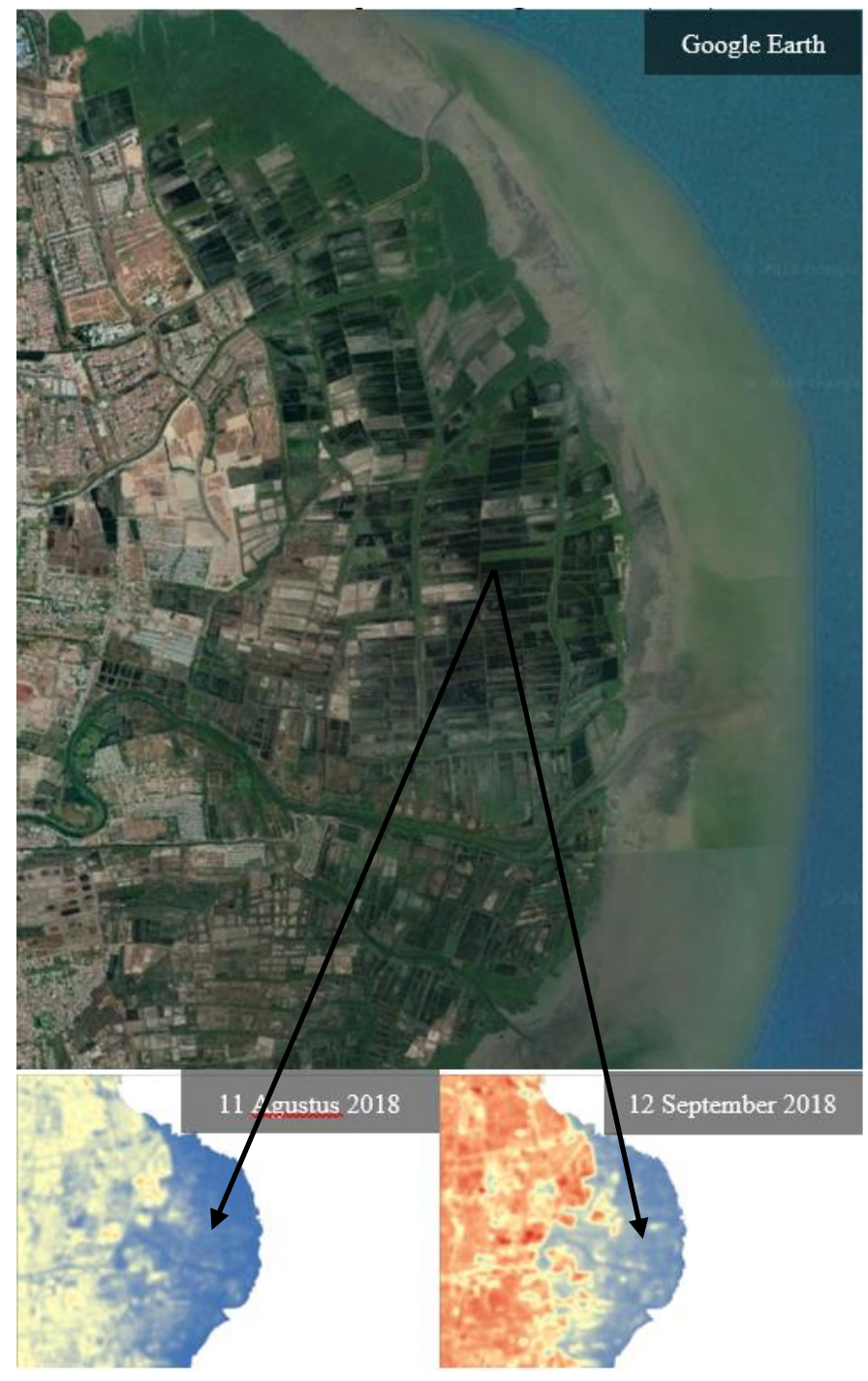

Gambar 6. Anomali pola suhu rendah pada Surabaya Timur

\section{Hasil Pengolahan Automatic Weather Station (AWS)}

Dalam pengolahan data meteorologi, data diharuskan tersusun atas besaran yang berstandar internasional (SI) atau memiliki besaran yang sama. Pada penelitian ini besaran yang digunakan antara lain waktu $(\mathrm{GMT}+7)$, suhu $\left({ }^{\circ} \mathrm{C}\right)$, tekanan ( $\left.\mathrm{hPa}\right)$ dan kelembaban (\%). Data yang telah terintegrasi selanjutanya dimodelkan pada grafik pola 
perubahan suhu pada PWS ITS dan BMKG Juanda. Variasi SPT Kota Surabaya dapat dilihat pada Gambar 7 dan 8. Variasi SPT Kota Surabaya memiliki pola kenaikan suhu pada pukul 06.00 WIB dan mencapai puncak pada 12.00 kemudian suhu berkurang seiring dengan turunnya intensitas matahari yang menyinari. Pada PWS ITS tercatat bahwa suhu maksimum adalah $36^{\circ} \mathrm{C}$, suhu minimumnya adalah $21^{\circ} \mathrm{C}$ dan suhu rata-ratanya adalah $28^{\circ} \mathrm{C}$. Sedangkan pada BMKG Juanda tercatat bahwa suhu maksimum adalah $33^{\circ} \mathrm{C}$, suhu minimumnya adalah $20^{\circ} \mathrm{C}$ dan suhu rata-ratanya adalah $27^{\circ} \mathrm{C}$.

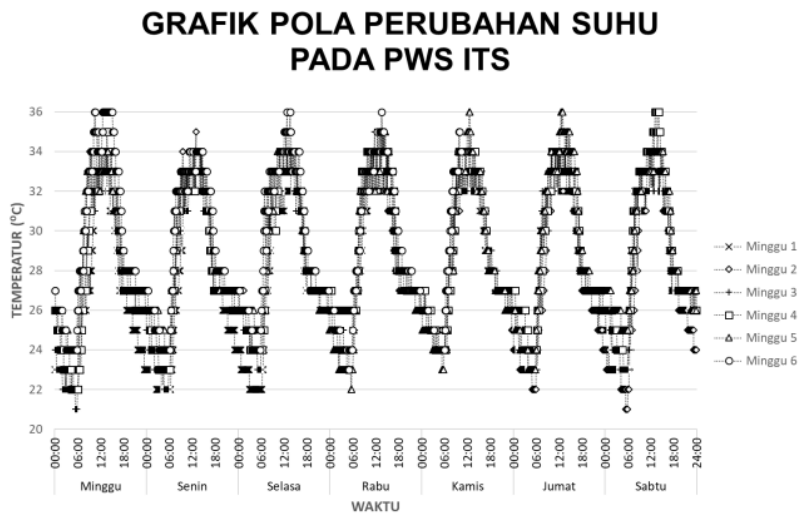

Gambar 7. Grafik pola perubahan suhu bulanan pada PWS ITS

\section{GRAFIK POLA PERUBAHAN SUHU PADA STASIUN BMKG JUANDA}

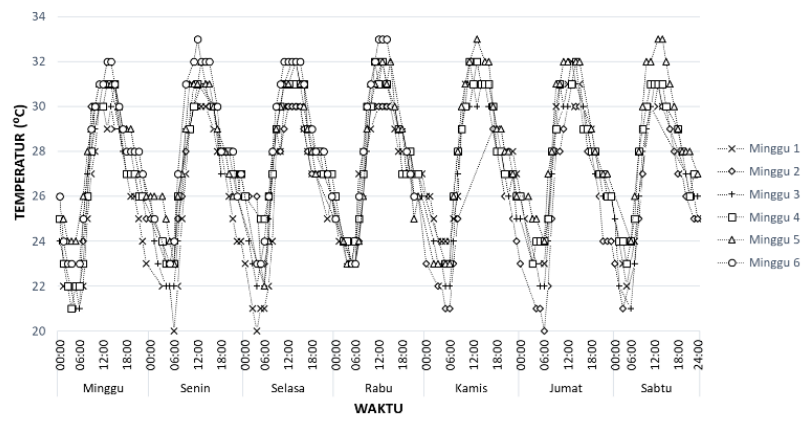

Gambar 8. Grafik pola perubahan suhu bulanan pada PWS ITS

Selain untuk memperoleh variasi SPT secara temporal, variasi SPT secara spasial juga dilakukan dengan melakukan eksterpolasi pada data SPT yang diperoleh dari AWS. Data SPT yang digunakan dalam proses ekstrapolasi sesuai dengan waktu akuisisi citra Landsat 8 yaitu 11 Agustus 2018 dan 12 September 2018 pukul 09.35. PWS ITS dan BMKG Juanda memiliki waktu perekaman yang berbeda, sehingga dilakukan interpolasi agar waktu perekaman SPT pada AWS sama dengan waktu akuisisi data citra Landsat 8. Metode interpolasi yang digunakan untuk memperoleh variasi SPT secara spasial adalah IDW. Hasil pengolahan IDW dipotong menggunakan tools extract by mask dengan shp batas administrasi Kota Surabaya. hasil akhir pengolahan ekstrapolasi data suhu dapat dilihat pada Gambar 9 dan 10. Berikut adalah tabel yang menjelaskan tentang data untuk pengolahan interpolasi:

Tabel 2. Data Meteorologi Untuk Pengolahan Interpolasi

\begin{tabular}{ccccccc}
\hline \hline Waktu & $\begin{array}{c}\text { Nama } \\
\text { Stasiun }\end{array}$ & $\mathrm{T}(\mathrm{m})$ & $\mathrm{U}(\mathrm{m})$ & $\begin{array}{c}\text { Suhu } \\
\left({ }^{\circ} \mathrm{C}\right)\end{array}$ & $\begin{array}{c}\text { Tekanan } \\
(\mathrm{hPa})\end{array}$ & $\begin{array}{c}\text { Kelembaban } \\
(\%)\end{array}$ \\
\hline \multirow{2}{*}{$11 / 08 / 18$} & Juanda & 695362 & 9182749 & 31,00 & 1013,02 & 55,00 \\
& ITS & 698718 & 9193796 & 33,00 & 1015,16 & 36,00 \\
& \multirow{2}{*}{ Juanda } & 695362 & 9182749 & 27,98 & 1011,00 & 65,00 \\
& ITS & 698718 & 9193796 & 33,00 & 1014,00 & 43,00 \\
\hline \hline
\end{tabular}

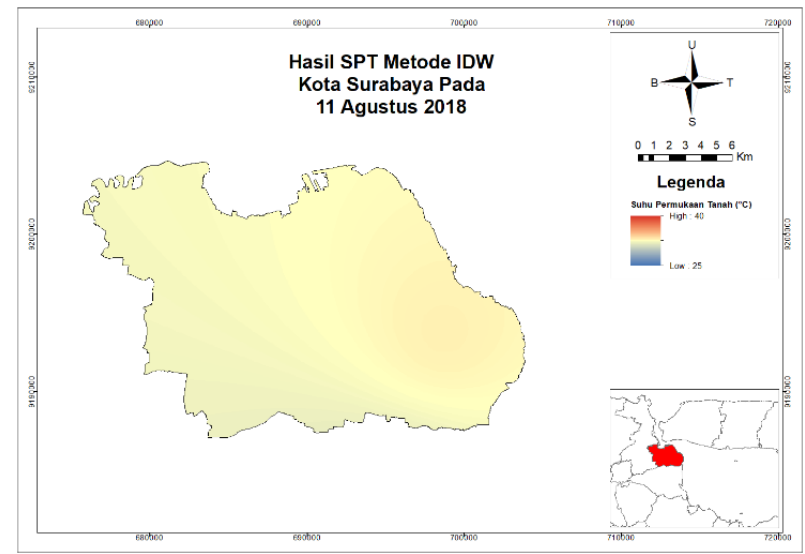

Gambar 9. Hasil ekstrapolasi data SPT AWS menggunakan metode IDW pada 11 Agustus 2018

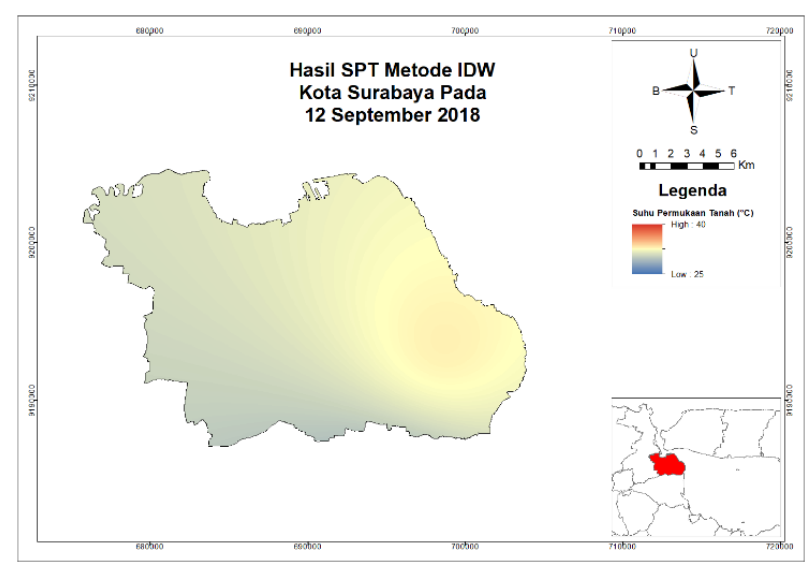

Gambar 10. Hasil ekstrapolasi data SPT AWS menggunakan metode IDW pada 12 September 2018 
Hasil esktrapolasi data SPT yang diperoleh dari AWS menggunakan metode IDW pada 11 Agustus 2018 dan 12 September 2018 dijelaskan pada Gambar 9 dan 10. Perubahan warna pada hasil pengolahan memiliki makna yang berbeda, warna merah berarti SPT yang tinggi dan warna hijau berarti SPT yang rendah.

\section{Analisis Grafik}

Pemodelan pola perubahan SPT yang diperoleh dari AWS dilakukan menjadi 2 yaitu pemodelan pola perubahan SPT harian dan bulanan. Pemodelan pola perubahan SPT harian dilakukan untuk mengetahui perbandingan pola perubahan suhu pada kedua AWS dan untuk mengetahui pola perubahan suhu dalam satu hari yang sama. Dalam pemodelan pola perubahan SPT harian menggunakan waktu yang sama dengan akuisisi data citra satelit Landsat 8 yaitu 11 Agustus 2018 dan 12 September 2018.

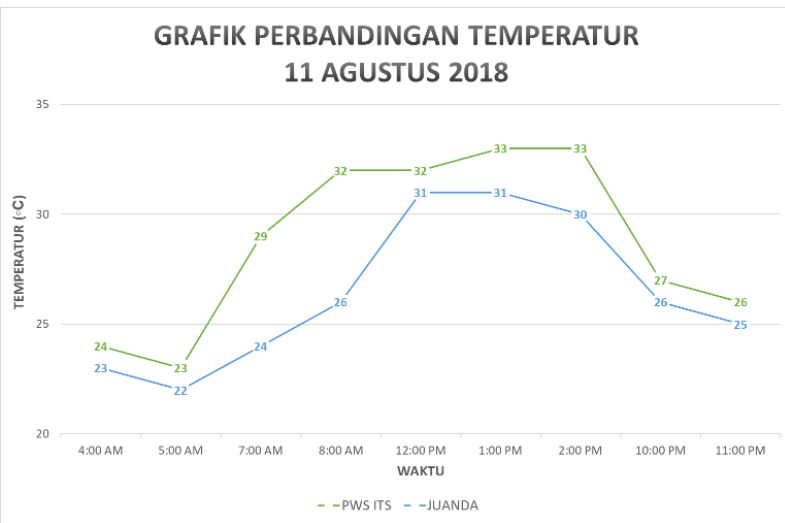

Gambar 11. Grafik perbandingan suhu PWS ITS dan BMKG Juanda pada 11 Agustus 2018

GRAFIK PERBANDINGAN TEMPERATUR 12 SEPTEMBER 2018
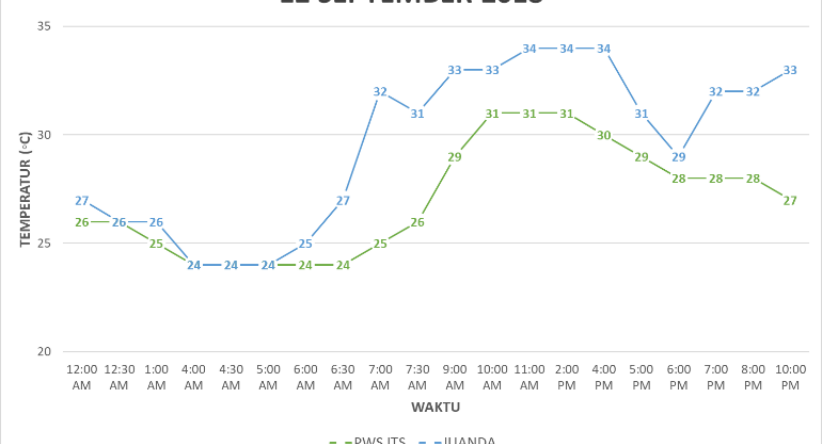

Gambar 12. Grafik perbandingan suhu PWS ITS dan BMKG Juanda pada 12 September 2018

Pemodelan pola perubahan SPT bulanan dilakukan untuk mengetahui pola perubahan suhu
Kota Surabaya dalam 1 bulan. Pemodelan pola perubahan SPT bulanan bertujuan untuk mengetahui nilai maksimum, minimum dan ratarata suhu Kota Surabaya. Hasil perbandingan pola perubahan SPT harian Kota Surabaya dapat dilihat pada Gambar 11 dan 12.

Pada Gambar 11 dan 12 menjelaskan bahwa pada 11 Agustus 2018 pola perubahan suhu yang diperoleh dari PWS ITS dan Stasiun BMKG Juanda memiliki pola yang sama, yaitu suhu mulai meningkat pada pagi hari (05.00 WIB) dan mencapai puncak pada siang hari (12.00 - 13.00 WIB). Grafik tersebut berkorelasi dengan grafik perbandingan suhu pada 12 September 2018.

Hasil perbandingan SPT yang diperoleh dari BMKG Juanda dengan pengolahan AWS metode SCA pada 11 Agustus 2018 adalah $\pm 0,11^{\circ} \mathrm{C}$. Sedangkan perbandingan SPT yang diperoleh dari PWS ITS adalah $\pm 0,88^{\circ} \mathrm{C}$. Hasil perbandingan SPT yang diperoleh dari PWS ITS dengan pengolahan AWS metode SCA pada 12 September 2018 adalah $\pm 0,34^{\circ} \mathrm{C}$. Sedangkan perbandingan SPT yang diperoleh dari PWS ITS adalah $\pm 3,22^{\circ} \mathrm{C}$. Selanjutnya data suhu tersebut dimasukkan sebagai variabel dalam perhitungan uji korelasi. Hal tersebut dapat dilihat pada Tabel 3 tentang perbandingan SPT yang diperoleh dari AWS dengan pengolahan SPT metode SCA. SPT yang diperoleh AWS dan hasil pengolahan SPT metode SCA diuji korelasi untuk mendapatkan nilai koefisien korelasi. Uji korelasi yang digunakan untuk mendapatkan nilai koefisien korelasi dari SPT yang diperoleh dari AWS dengan hasil pengolahan SPT metode SCA adalah uji korelasi pearson (Istantinova, et, al., 1995):

Tabel 3. Perbandingan SPT yang diperoleh dari AWS dengan pengolahan SPT metode SCA

\begin{tabular}{ccccc}
\hline \hline Waktu & $\begin{array}{c}\text { Nama } \\
\text { Stasiun }\end{array}$ & AWS & $\begin{array}{c}\text { Suhu }\left({ }^{\circ} \mathrm{C}\right) \\
\text { SPT Metode } \\
\text { SCA }\end{array}$ & $\Delta \mathrm{t}\left({ }^{\circ} \mathrm{C}\right)$ \\
\hline \multirow{2}{*}{$11 / 08 / 18$} & Juanda & 27,98 & 28,09 & 0,11 \\
& ITS & 33 & 32,12 & $-0,88$ \\
$12 / 09 / 18$ & Juanda & 31 & 31,34 & 0,34 \\
& ITS & 33 & 36,22 & 3,22 \\
\hline \hline
\end{tabular}

Hasil uji korelasi pearson yang diperoleh adalah 0,87 yang memiliki arti korelasi yang sangat kuat hal ini dapat dilihat pada Tabel 4 tentang hasil uji korelasi pearson. Nilai koefisien korelasi diperoleh karena pola perubahan suhu yang ditunjukkan oleh data suhu AWS dan SPT Metode SCA relatif sama 
yaitu tinggi pada PWS ITS dan rendah pada Stasiun BMKG Juanda. Letak PWS ITS dikelilingi bangunan dan pemukiman sedangkan Stasiun BMKG Juanda dikelilingi sawah dan bangunan bandara.

Tabel 4. Hasil uji korelasi pearson

\begin{tabular}{|c|c|c|c|c|c|c|}
\hline Waktu & $\begin{array}{l}\text { Nama } \\
\text { Stasiun }\end{array}$ & AWS $(X)$ & $\begin{array}{l}\text { SPT } \\
\text { SCA } \\
\text { (Y) }\end{array}$ & $x^{2}$ & $Y^{2}$ & $X Y$ \\
\hline \multirow{2}{*}{$11 / 08 / 2018$} & Juanda & 27,98 & 28,09 & 782,88 & 789,05 & 785,96 \\
\hline & ITS & 33,00 & 32,12 & 1089,00 & 1031,69 & 1059,96 \\
\hline \multirow{2}{*}{$12 / 09 / 2018$} & Juanda & 31,00 & 31,34 & 961,00 & 982,20 & 971,54 \\
\hline & ITS & 33,00 & 36,12 & 1089,00 & 1304,65 & 1191,96 \\
\hline Total ( $\Sigma)$ & : & 124,98 & 127,67 & 3921,88 & 4107,59 & 4009,42 \\
\hline Rata-rata & : & 31,25 & 31,92 & 980,47 & 1026,90 & 1002,35 \\
\hline $\mathrm{R}_{\mathrm{xy}}$ & : & 0,87 & & & & \\
\hline
\end{tabular}

\section{Analisis Perbandingan Hasil Akhir}

Perbandingan hasil akhir dilakukan dengan membandingkan Gambar 2 tentang hasil hasil pengolahan SPT metode SCA pada citra Landsat 8 akuisisi 11 Agustus 2018 dengan Gambar 9 tentang hasil ekstrapolasi data SPT AWS menggunakan metode IDW pada 11 Agustus 2018. Hasil dari perbandingan tersebut adalah interpolasi data suhu tidak berkorelasi dengan hasil pengolahan SPT metode S CA dikarenakan kurangnya AWS pada bagian pusat Kota Surabaya dan Surabaya Utara, sehingga perbandingan hasil akhir terlihat jauh berbeda.

Hal ini dapat dilihat dari suhu pada pusat Kota Surabaya yang seharusnya tinggi dan pada bagian timur Kota Surabaya yang berupa tambak seharusnya memiliki suhu yang rendah. Suhu pada pusat Kota Surabaya relatif lebih tinggi karena intensitas aktifitas kendaraan bermotor seperti mobil dan motor yang tinggi. Sedangkan pada bagian timur Kota Surabaya sebagian besar adalah tambak dan penangkaran mangrove.

Pada 12 September juga menunjukkan hasil yang sama dikarenakan kurangnya data stasiun cuaca pada pusat Kota Surabaya dan bagian utara Kota Surabaya sehingga hasil pengolahan IDW kurang akurat.

\section{KESIMPULAN}

Hasil pengolahan SPT metode SCA pada stasiun BMKG Juanda pada 11 agustus dan 12 september adalah $28,09^{\circ} \mathrm{C}$ dan $31,34^{\circ} \mathrm{C}$, sedangkan pada PWS ITS adalah $32,12^{\circ} \mathrm{C}$ dan $36,12^{\circ} \mathrm{C}$. Pada hasil pengolahan SPT terdapat beberapa pola distribusi 272 suhu yang sangat signifikan perbedaannya. Anomali-anomali yang dimaksud antara lain pola suhu rendah yang membentuk jalur dan setelah ditelusuri anomali tersebut adalah Sungai Jagir, selain itu terdapat hotspot pada bagian Barat Kota Surabaya dan setelah ditelusuri anomali tersebut adalah aktifitas Gasifikasi pada TPA Benowo dan anomali yang terakhir adalah pola suhu rendah pada Surabaya Timur dan setelah ditelusuri anomali tersebut adalah tambak dan hutan mangrove. Pemodelan perubahan suhu bulanan menunjukkan model yang sama setiap harinya yaitu suhu mulai naik pada pagi hari pukul 05.00 WIB dan mencapai puncak pada siang hari yaitu 12.00 WIB hingga 13.00 WIB. Hasil yang diperoleh dari interpolasi data suhu tidak berkorelasi dengan hasil pengolahan SPT metode SCA dikarenakan kurangnya data pada bagian pusat kota surabaya, sehingga perbandingan hasil akhir terlihat jauh berbeda

\section{DAFTAR PUSTAKA}

Hakim, A. 2018. Risma : Suhu di Surabaya Turun 2 Derajat Celcius. Antaranews Jatim.

Prasasti, I., Sambodo, K. A., \& Carolita, I. 2007. Pengkajian Pemanfaatan Data TERRA-MODIS Untuk Ekstraksi Data Suhu Permukaan Lahan (SPL) Berdasarkan Beberapa Algoritma. LAPAN, 4(1), 1-8.

Rajeshwari, A., \& Mani, N. D. 2014. Estimation of Land Surface Temperature of Dindigul District Using Landsat 8 Data. International Journal of Research in Engineering and Technology (IJRET), 3(5), 122-126.

Landsat 8 OLI And TIRS Calibration Notices. 2017. Retrieved June 13, 2019, From Https://www.Usgs.Gov/Land-Resources/Nli/ Landsat/Landsat-8-Oli-And-Tirs-CalibrationNotices

Walawender, J. A. P. W., Zymanowski, M. A. S., Ajto, M. O. J. H., \& Okwa, A. N. B. 2014. Land Surface Temperature Patterns in the Urban Agglomeration of Krakow ( Poland) Derived from Landsat-7 / ETM + Data, 171, 913-940. https://doi.org/10.1007/s00024-013-0685-7

Tsou, J., Zhuang, J., Li, Y., \& Zhang, Y. 2017. Urban Heat Island Assessment Using The Landsat 8 Data: A Case Study In Shenzhen And Hong Kong. Urban Science, 1(1), 10.

Qudratullah, M. I., Kamus, Z., \& Asrizal. 2017. Analisis Unsur-Unsur Cuaca Berdasarkan Hasil Pengukuran Automated Weather System (AWS) Tipe Vaisala Maws 201. Pillar Of Phyiscs, 9, 1724. 
Nugroho, G. A., Machfud, M. S., \& Sanjaya, M. 2016. Rancang Bangun Automatic Weather Station (Aws) Menggunakan Raspberry Pi. Alhazen Journal Of Physics, II(2), 48-57.

Jaelani, L. M. 2013. Kalibrasi Radiometrik: Mengubah Digital Number (DN) ke Radiance dan/atau Reflectance. Retrieved January 16, 2019, from http://Imjaelani.com/2013/12/kalibrasiradiometrik-mengubah-digital-number-dn-keradiance-danatau-reflectance/

Waas, H. J. D., \& Nababan, B. 2010. Pemetaan dan analisis index vegetasi mangrove di pulau Saparua, Maluku Tengah. E-Jurnal Ilmu Dan Teknologi Kelautan Tropis, 3(2), 50-58.

Sobrino, J. A., \& Raissouni, N. 2000. Toward Remote Sensing methods for land cover dynamic monitoring. Application to Morocco. International Journal of Research in Engineering and Technology (IJRET), 21, 353366.

Sobrino, J. A., Casseles, V., \& Becker, F. 1990. Significance of the remotely sensed thermal infrared measurements obtained over a citrus orchard. ISPRS J. Photogramm, 44, 343-354.

Walawender, J. P., Szymanowski, M., Hajto, M. J., \& Bokwa, A. 2014. Land Surface Temperature Patterns in the Urban Agglomeration of Krakow (Poland) Derived from Landsat7/ETM+ Data. Pure and Applied Geophysics, 171(6), 913-940. https://doi.org/10.1007/s0 0024-013-0685-7

Barsi, J. A., Barker, J. L., \& Schott, J. R. 2003. An Atmospheric Correction Parameter Calculator for a Single Thermal Kanal Earth-Sensing Instrument. IEEE IGARSS. Toulouse, France.

Jimenez-Munoz, J. C., Cristobal, J., Sobrino, J. A., Soria, G., Ninyerola, M., \& Pons, X. 2009. Revision of the Single- Channel Algorithm for Land Surface Temperature Retrieval From Landsat ThermalInfrared Data. IEEE Trans. Geosci. Remote Sensing, 47, 339-349.

Sobrino, J. 2010. A Single-Channel Algorithm for LandSurface Temperature Retrieval From ASTER Data, (February), 3-7. https://doi.org/10.11 09/LGRS.2009.2029534

Hidayat, A. 2012. Uji Pearson Product Moment dan Asumsi Klasik. Retrieved June 23, 2019, from https://www.statistikian.com/2012/07/pearson -dan-asumsi-klasik.html/amp

Sarwono, J. 2006. Metode Penelitian Kuantitatif dan Kualitatif (Edisi pert). Yogyakarta: Graha IImu.

Dofir, M. 2018. Sampah Warga Surabaya di TPA Benowo Dirubah Jadi Energi Listrik. Faktualnews.Co. Retrieved from https://faktualnews.co/2018/06/29/sampahwarga-surabaya-di-tpa-benowo-dirubah-jadienergi-listrik/86411/

Istantinova, D. B., Hadiwidodo, M., \& Handayani, D. S. 1995. Terhadap Konsentrasi Gas Pencemar Sulfur Dioksida ( So 2 ) Dalam Udara Ambien Di Sekitar Pt . Inti General Yaja Steel Semarang Abstrak. Tentang Konsentrasi Gas Sulfur, 10(Gas Sulfur), 1-10. 